\title{
RELIEF CANDI SEBAGAI MEDIA EFEKTIF UNTUK MENYAMPAIKAN INFORMASI MORAL-DIDAKTIF PADA MASA JAWA KUNA
}

\section{THE RELIEF OF CANDI AS AN EFFECTIVE MEDIA TO DELIVER MORAL-DIDACTIC MESSAGE IN ANCIENT JAVA}

\author{
T.M. Hari Lelono \\ Balai Arkeologi D.I. Yogyakarta \\ harilono@gmail.com
}

\begin{abstract}
The establishment of temple as sacred buildings of Shivaism/Buddhism in Ancient Javanese Period aimed to worship gods. Temples are, decorated by reliefs contain moraleducational message to support their aim. Stories or non stories depicted on the relief functioned as information/publication medium for adult as well as children. This article examines why relief was used in Hinduism-Buddhism Period to deliver moral-educational message to them. Methods used is observation on the relief stories carved on temples in Central and East Jav, analysis, and interpretation based on literature study.
\end{abstract}

Keywords: Temple Reliefs, Media Information, Javanese.

\begin{abstract}
ABSTRAK
Pada masa Jawa Kuna, pendirian bangunan suci Siwa/Hindu-Buddha dimaksudkan untuk tempat melakukan pemujaan kepada para dewa. Arsitektur candi yang indah biasanya dihiasi dengan relief yang berisi pesan moral-edukatif. Relief dapat dimaknai sebagai salah satu media informasi/ publikasi yang ditujukan kepada masyarakat luas baik dewasa maupun anak-anak. Tujuan tulisan ini, adalah untuk mengetahui mengapa relief digunakan oleh nenek moyang pada masa Klasik (Hindu-Budha) sebagai media untuk menyampaikan pesan moral-edukasi bagi masyarakat. Metode yang digunakan dalam penelitian ini adalah observasi terhadap relief cerita candi-candi di Jawa Tengah dan Timur, analisis, serta interpretasi yang didukung oleh studi literatur.
\end{abstract}

Kata Kunci: Relief Candi, Media Informasi, Jawa Kuna.

Tanggal masuk : 15 Maret 2016

Tanggal diterima : 31 Mei 2016 


\section{PENDAHULUAN}

Masa klasik di Indonesia atau dikenal dengan masa HinduBuddha ditandai dengan adanya tinggalan tangible maupun intangible. Tinggalan tangible berupa bangunan-bangunan monumental religius seperti candi-candi tersebar di Pulau Sumatera, Kalimantan, Bali dan Jawa. Tinggalan lain yang intangible dalam bentuk adat dan tradisi juga masih tetap ada dalam kehidupan sehari-hari masyarakat. Kedatangan agama Hindu-Buddha beserta segala aturannya sebagai budaya India tidak melenyapkan budaya/ tradisi asli Indonesia yang telah ada, namun bercampur atau saling mempengaruhi. Percampuran tersebut memunculkan budaya baru yang kini diwarisi oleh bangsa Indonesia.

Cerita rakyat di berbagai belahan dunia, selalu dikaitkan dengan kebudayaan yang dialaminya. Cerita rakyat dari Polinesia menggambarkan bahwa mereka masih mempunyai cerita yang mengandung mitos yang sarat akan muatan filosofis. Mitos-mitos mereka menunjukkan adanya perilaku budaya yang sangat tinggi dari kelompok suku tertentu yang berguna untuk penguatan identitas generasi berikut. Cerita rakyat tersebut juga berisi tentang nilai-nilai pendidikan, usaha untuk menggalang solidaritas yang disertai dengan cerita yang menghibur. Dengan demikian maka cerita rakyat memberikan inspirasi bagi para pemeluk suatu kebudayaan untuk memiliki perasaan bangga atas suku bangsanya (Liliweri, 2007: 126).

Nilai-nilai moral, didaktif dan filosofis yang ada dalam cerita rakyat yang menggambarkan kehidupan manusia dan hewan. Cerita ini hidup dalam setiap kebudayaan di dunia dan menyebabkan tercapainya suatu keharmonisan antara alam (florafauna) dengan manusia. Cerita rakyat juga berkembang dengan pesat di Jawa dan sering didongengkan pada anak-anak menjelang tidur. Pada masa sekitar tahun 1960 - 1980-an masih sering didengarkan dongeng menjelang tidur, dari para orang tua kepada anak-anaknya tentang cerita fabel yang lucu dan penuh simbol-simbol, seperti cerita Kancil dengan Seruling Bambu: Kancil dengan Harimau, Bangau dengan Kura-Kura. Kebiasaan yang turun-temurun tersebut, tentunya ada sumbernya entah berupa naskah-naskah yang diwariskan, melalui oral atau yang terdapat di dalam relief candi. Kebiasaan tersebut, apakah dilakukan oleh para nenek moyang pada masa Jawa kuna? belum diketahui secara pasti. Namun, relief fabel pada dinding candi tentu bukan sekadar hiasan, tetapi merupakan media untuk menyampaikan infomasi

Sebelum masuknya pengaruh India di Indonesia, nenek moyang kita telah mengenal budaya yang diantaranya adalah berupa ragam hias dari zaman prasejarah serta berbagai benda keperluan upacara seperti nekara, kapak perunggu, dan wadah-wadah mayat (Atmosudiro, dkk. 2008: 155).

Kontak percampuran ataupun sintesa dengan kebudayaan lain, dalam hal ini budaya India mencetuskan kebudayaan dan kesenian yang harmonis, dinamik, dan unik sesuai dengan jiwa masyarakat lokal. Kebudayaan lokal yang pada mulanya ditujukan sebagai bentuk pemujaan terhadap nenek moyang tersebut kemudian lambat laun bercampur dengan pengaruh kebudayaan baru yang 
datang ${ }^{1}$ menjadi kreasi seni berupa ornamen-ornamen

candi.

Selanjutnya, muncullah ragamragam hias berupa penggambaran manusia, tumbuh-tumbuhan, dan binatang. Gambar-gambar tersebut dibuat sedemikian rupa sehingga terwujud suatu bentuk tertentu. Bentuk alam asli, seperti misalnya gambar-gambar tumbuh-tumbuhan merambat/ menjalar menghiasi bidang batas/ frame relief, atau penggambaran binatang yang sesuai dengan fauna yang ada. Khususnya gambar flora merambat distilir terlebih dahulu sesuai dengan bakat dan kemampuan seniman, maupun digambarkan berdasarkan ragam-ragam yang bersifat turun temurun. Pengaruh Hindu-Buddha juga mendorong perkembangan motif-motif hiasan dan relief-relief yang dipahat pada candi-candi. Selain memiliki nilai estetika, relief yang dipahatkan pada bidang datar baik di bagian kaki, badan atau atap candi, juga memiliki nilai simbolisreligius yang dapat digunakan untuk menentukan identitas keagamaan candi (Istari, 2011: 1-2).

Panel-panel relief yang dipahatkan di dinding candi, merupakan salah satu bentuk kearifan lokal masyarakat Jawa, dalam mengadopsi dan mengatasi pengaruh budaya asing. Mereka bukanlah orang yang tertutup sifatnya, namun terbuka terhadap hal-hal yang dianggap baik dan masih relevan dengan budaya

\footnotetext{
${ }^{1}$ Akulturasi dan asimilasi, mengenai proses sosial yang timbul bila suatu kelompok manusia dengan suatu kebudayaan tertentu dihadapkan dengan unsur-unsur dari suatu kebudayaan asing dengan sedemikian rupa, sehingga unsur-unsur kebudayaan asing itu lambat laun diterima dan diolah kedalam kebudayaan sendiri tanpa menyebabkan hilangnya kebpribadian kebudayaan itu sendiri (Koentjaraningrat, 1980: 262).
}

aslinya. Orang Jawa memilih budaya yang sesuai untuk dapat diterima dalam budayanya. Dalam konteks tersebut, relief adalah salah satu bentuk dari kearifan lokal (local genius).

Local genius dapat dianggap sama dengan apa yang saat ini terkenal dengan istilah cultural identity atau identitas budaya karena menunjukkan kemampuan suatu bangsa dalam menyerap serta mengolah pengaruh kebudayaan asing, sesuai dengan watak dan kebutuhan pribadinya. Pada penekanan aspek lain, ${ }^{2}$ kemampuan itu dinamakan 'ketahanan', terutama ketahanan di bidang budaya, atau yang kini disebut ketahanan bangsa. Ketahanan ini menyebabkan suatu bangsa lebih mampu untuk 'bertahan' menghadapi 'ancaman' kebudayaan yang datang dari luar. Akibat adanya ketahanan ini adalah kemampuan untuk menyerap hal yang sesuai dengan kebutuhan mereka, dan menolak apa yang tidak sesuai bagi mereka (Subadio, 1986: 18).

Suatu hal yang menarik pada relief adalah penggambaran cerita bermuatan pesan-pesan moral kepada masyarakat, khususnya bagi pendidikan anak. Jenis cerita yang banyak digambarkan pada relief adalah fabel ${ }^{3}$ dengan makna simbolis, jenaka, tetapi penuh pesan moral serta mudah dicerna bagi siapa saja yang melihatnya, terutama anak-anak. Berkaitan dengan local-genius, relief dapat

\footnotetext{
2 Seperti misalnya; unsur-unsur budaya berupa nilai-nilai yang hidup dalam adatistiadat dan tradisi masyarakat, berdasarkan pada lingkungan dan budaya yang bisa mempengaruhi perilaku sehari-hari.

${ }^{3}$ Fabel, cerita yang menggambarkan watak dan budi manusia yang pelakunya diperankan oleh binatang, berisi pendidikan moral dan budipekerti. (KBBI, 2012:386)
} 
digunakan untuk ketahanan bangsa.

Relief digambarkan atas ide-ide seniman dengan mengacu pada kaidah-kaidah religius dan adat kebiasaan masyarakat sesuai dengan alam dan budaya dengan mengacu pada bahan materi yang berasal dari lingkungannya. Keterbatasan media yang dapat digunakan untuk menyampaikan pesan-pesan, kemungkinan dipilih candi sebagai media yang strategis dan dapat bertahan lama. Tentu bentuk-bentuk komunikasi lainnya telah dilakukan, misalnya secara oral dari orang ke orang. Namun, melalui relief candi informasi tersebut akan bertahan sampai berabad-abad. Hal tersebut merupakan usaha dari para penguasa masa Jawa Kuna untuk membuka wawasan dan pengetahuan rakyatnya dalam hal religi dengan menggambarkan dongeng dalam relief. Sehubungan dengan hal tersebut, maka pertanyaan yang diajukan dalam tulisan ini adalah: Mengapa penguasa menggunakan relief berisikan cerita-cerita moral-didaktif untuk menyampaikan pesanpesannya kepada rakyatnya? Oleh sebab itu tujuan paper ini ingin mengungkapkan bahwa relief merupakan salah satu media informasi yang efektif untuk menyampaikan pesan moral-didaktif. Dalam relief, diungkapkan magnamagna simbolis yang di perankan oleh para 'tokoh binatang' dalam unsur cerita yang dikemas secara dinamis sebagai salah satu unsur pendidikan yang mudah dicerna dan dipahami.

\section{METODE PENELITIAN}

Relief memiliki bermacam-

macam bentuk dan makna simbolis yang terkandung di dalamnya. Hal tersebut tergantung isi pesan yang akan disampaikan. Relief non-cerita bergambar flora (tumbuhan), fauna (binatang) memiliki makna simbolis yang berhubungan dengan bangunan suci. Penelitian ini menggunakan alur penalaran induktif dengan tipe deskriptif. Salah satu tujuan penelitian deskriptif ini adalah untuk menyajikan gambaran mengenai fenomena masyarakat Jawa kuna, tentang bagaimana cara menyampaikan informasi dalam bentuk pesan-pesan kultural edukatif dalam bentuk visual (relief candi) kepada masyarakat. Berdasarkan hal tersebut, makalah ini bertujuan untuk menjawab permasalahan, sejauh mana 'relief candi berperan sebagai media komunikasi/ informasi'.

Jenis data yang digunakan berupa relief cerita candi Siwa/Hindu-Buddha yang terdapat pada dinding-dinding candi. Seluruh perolehan data hasil observasi berupa relief cerita fabel yang berhasil dikumpulkan, kemudian dianalisis secara kualitatif dan akan diuraikan secara deskriptif. Sebagai hasil dari pembahasan tersebut, disusun kesimpulankesimpulan interpretatif yang dapat memberikan gambaran tentang peran relief sebagai 'media informasi/ komunikasi' yang efektif untuk menyampaikan pesan moral kepada masyarakat pada masa lampau.

\section{RELIEF: PERPADUAN BUDAYA ASLI DAN ASING}

Agama Buddha dan Hindu berasal dari India, masuk bersamaan dengan datangnya para pedagang. Pengaruh agama tersebut berkembang pesat setelah bercampur dengan kepercayaan asli 
Indonesia yang sudah ada sebelumnya, yaitu pemujaan terhadap roh leluhur (megalitik). Pengaruh 'asing' tersebut tidak serta-merta diterima dengan mudah, unsur-unsur yang sesuai bahkan terjadi percampuran, dan memunculkan budaya baru dalam konteks religi tersebut. Hal tersebut, sesuai apa yang dikatakan oleh Edy Sedyawati, bahwa kebudayaan yang sudah ada pada suatu bangsa seringkali terbawa unsur-unsurnya ketika bertemu dan beradopsi dengan budaya asing. Aspek budaya terpilah ke dalam sejumlah wujud dan unsur. Pertama dapat disebutkan konsep-konsep dan nilainilai. Sebuah agama yang baru diperkenalkan dapat memasok sebuah konsep dan nilai baru dan dengan demikian turut mengubah citra budaya suatu bangsa. Demikian pula dalam tata laku, tata ruang, serta penggunaan dan atau pembuatan benda-benda tertentu, pasokan kaidah dari agama dapat pula berperan dalam perubahan citra budaya. Namun sebaliknya juga, wujud-wujud budaya lama dapat pula memberi 'warna lokal' kepada agama baru yang diperkenalkan, melalui suatu proses asimilasi (Sedyawati, 2009: 208).

Dalam

perkembangan

percampuran dan 'saling pengaruh' kepercayaan dari 'luar' dan asli Indonesia tersebut, salah satu contoh diwujudkan dalam penggambaran relief cerita. Unsur utama berasal dari mitologi HinduBuddha yang diadoptasikan dengan unsur-unsur mitos lokal dan digambarkan dari bentuk-bentuk fauna/ flora asli Indonesia, seperti misalnya kancil, harimau, kepiting (ketam), angsa, kura-kura, dan lainnya. Di India, mungkin memiliki beberapa jenis binatang yang sama, tetapi para seniman memilih binatang lokal yang biasa mereka ketahui. Selain dalam bentuk faunaflora, diduga tidak kalah penting adalah unsur cerita yang mereka rancang, tentunya unsur budaya lokal menjadi pertimbangan utama agar tidak menimbulkan persepsi/ salah tafsir dalam cerita yang akan dipahatkan dalam relief candi.

Cerita-cerita dengan pesan moral tersebut perlu disampaikan dengan suatu sistem yang efektif dan efisien dengan sarana prasarana yang dimiliki. Pada masa itu, salah satu media untuk melakukan komunikasi yang efektif adalah candi sebagai tempat untuk berkumpul dan melakukan ibadah. Komunikasi sangat berhubungan dengan bentuk-bentuk isyarat atau simbol yang berupa gerakangerakan jasmani, tanda gambar suara yang mengungkapkan pengertian tambahan salah satu komunikasi yang tertua dan paling sederhana ialah isyarat dan bahasa. Mula-mula perkembangan bahasa berasal dari gambar, kemudian berkembang menjadi bahasa berdasarkan uraian di atas maka manusia dapat berkomunikasi dengan cara: a) Menggunakan isyarat dan simbol; b) Menggunakan bahasa lisan; c) Menggunakan bahasa tertulis (Prabukusumo, 2009: 92). Dalam konteks penyampaian pesan moral melalui candi, pada masa Jawa Kuna, media yang digunakan sangat terbatas, sehingga relief yang dipahatkan dicandi merupakan sarana yang tepat untuk menyampaikan informasi dengan menggunakan gambar/ simbolsimbol flora-fauna.

Dalam proses pertemuan dua atau lebih unsur budaya, biasanya yang terjadi unsur-unsur asli yang bersifat substansional akan tetap tampak dalam percampuran tersebut. Salah satu unsur asli 
Indonesia tampak dalam karakteristik relief Jawa Timur mengkaitkan antara air, kesuburan dan kemakmuran, seperti di Teras Pendapa Candi Penataran, begitu pula relief Jawa Tengah di Candi Mendut dan Sojiwan (Klokke, 1993: 153). Hal ini dikarenakan unsurunsur asli diyakini dapat menenangkan kehidupan mereka.

Adapun unsur-unsur baru yang masuk/ bercampur, diselaraskan dan dipadukan sehingga memperoleh keharmonisan dalam pergaulan sosial dan religiusnya. Perpaduan antara budaya asli dengan budaya asing, dapat kita lihat pada gaya arsitektural bangunan candi dengan hiasan relief-reliefnya yang juga berfungsi sebagai media komunikasi.

\section{RELIEF SEBAGAI MEDIA KOMUNIKASI}

Relief sebagai media komunikasi, merupakan karya seni yang mengandung pesan religius yang dibuat atas perintah raja dibantu oleh para pendeta. Pengerjaan relief diserahkan kepada seniman pahat, sentuhan jiwa seni untuk diekspresikan dalam bentuk relief tersebut ditentukan oleh daya imajinasi seniman. Candi dengan hiasan relief, merupakan karya budaya material yang masih dapat dilihat hingga sekarang. Keindahan arsitektural bangunan suci tersebut membuktikan kemampuan budaya nenek moyang yang tinggi. Mereka bukan saja mampu mengadopsi pengaruh budaya asing (India) tetapi mampu mengembangkan sendiri local genius (kearifan lokal) yang sudah dimiliki sejak masa prasejarah dengan budaya perunggu/ metalurgi yang bernilai tinggi.

Berkaitan dengan tinggalan candi-candi di Jawa, khususnya di
Daerah Istimewa Yogyakarta, Jawa Tengah dan Jawa Timur, ditemukan relief-relief candi yang memuat unsur cerita maupun non-cerita. Beberapa buah relief candi yang mengandung unsur cerita, berfungsi sebagai sumber informasi resmi yang dikeluarkan oleh seorang raja akan dibahas dalam tulisan ini. Relief sebagai sumber informasi yang berisi cerita fabel, merupakan bahan untuk disebarluaskan kepada seluruh anggota masyarakat/ rakyat, melalui komunikasi di antara mereka. Cerita yang secara langsung berkaitan dengan konteks keagamaan, seperti misalnya Bubuksah-Gagang Aking kemungkinan berbeda cara menyampaikannya, karena cenderung untuk dikonsumsi orang dewasa. Tetapi cerita tentang Belibis dan Kura-Kura yang ditujukan kepada anak-anak, tentunya cara penyampaiannya berbeda, yaitu dengan lelucon, dan kejenakaan. Namun, kedua unsur cerita tersebut, tetap bersumber pada kaidah-kaidah keagamaan yang berkembang pada masa itu.

Penggambaran relief pada dasarnya berisi tentang keadaan alam, manusia dan lingkungannya, sehingga melalui relief dapat diungkap fenomena-fenomena alam, flora-fauna dan sosial masyarakat pada masa Jawa Kuna. Kondisi sosial masyarakat pada waktu itu dapat diketahui dari berbagai macam bentuk pakaian yang dikenakan, bentuk-bentuk arsitektur dan rumah tinggal, bentuk permukiman sebagai lanskap budaya, bahkan jenis komoditas perdagangan/ pasar dapat dilihat pada bermacam bentuk dan 'muatan' isi relief tersebut.

Dalam tulisan ini, akan dipilih beberapa relief yang ada di Candi Mendut, Jawa Tengah, Candi 
Penataran dan Surawana, Jawa Timur, berkaitan dengan fungsi dan peran relief sebagai 'media informasi'. Pertama, adalah menentukan cerita apa yang sesuai dengan tujuan membuat relief tersebut. Pemilihan cerita untuk dipahatkan pada dinding sebuah candi bukan suatu kebetulan, namun melalui sebuah pemikiran yang
Menurut Krom, nama lama Candi Penataran adalah 'Palah'. Hal ini diketahui dari prasasti berangka tahun 1119 Ç yang ditemukan di sebelah selatan candi induk. Prasasti ini berasal dari raja Çrengga, Kediri yang menyebutkan pendirian Dharma Bhatara di Palah, jika dilihat pada angka tahun pada prasasti yang

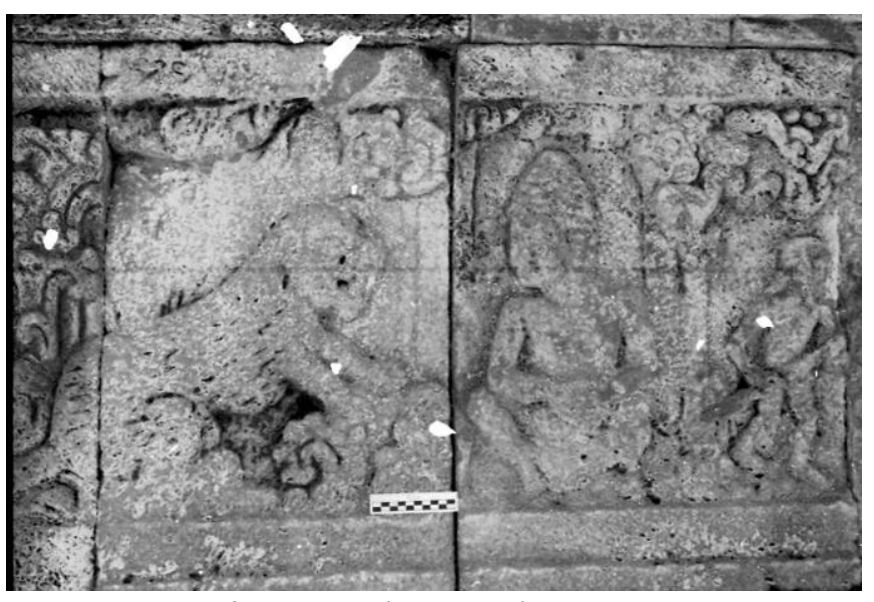

Gambar 1. Pendopo Candi Penataran:

Harimau jelmaan dewa menemui Bubuksah. Di latar tampak Gagang Aking yang memberitahu harimau agar memangsa Bubuksah. (Sumber: Balar D.I. Yogyakarta)

serius. Hal yang menjadi pertimbangan diantaranya berkaitan dengan fungsi candi, maupun sistem kepercayaan masyarakat pendukung candi. Dengan demikian, pemilihan cerita untuk dipahatkan pada dinding candi memiliki alasan tertentu, di samping cerita itu sendiri yang cenderung merupakan cerita yang terkenal pada masa bersangkutan (Sulistyanto, 2000: 2).

Pemilihan cerita relief ditentukan oleh para penguasa dan pendeta.

Mereka mempertimbangkan kepada siapa cerita dalam relief itu ditujukan. Di bawah ini adalah cerita-cerita yang ada pada relief beberapa candi:

\section{A. Relief Candi Penataran}

Candi Penataran merupakan kompleks percandian yang terbesar di Jawa Timur. ditemukan di belakang candi induk tersebut, diketahui bahwa Candi Penataran kira-kira didirikan sekitar tahun 1119 Ç atau 1197 M. Namun, dalam kenyataannya candi-candi di dalam kompleks Candi Penataran itu dibangun tidak dalam waktu bersamaan. Hal ini dapat dibuktikan dari beberapa prasasti berupa angka tahun yang terdapat di dinding-dinding bangunan yang tersebar di kompleks percandian. Seperti misalnya pada dinding batur Candi Pendopo terdapat angka tahun 1297 Ç (1375 M), pada arca Dwarapala Candi Bentar berangka tahun $1337 \mathrm{CS}$ (1415 M), pada dinding Candi Angka tahun terdapat tulisan tahun 1291 Ç (1369 M), sedangkan pada dinding kolam bagian barat 
kompleks percandian, terdapat pahatan angka tahun 1337 Ç (1415 M). Berdasarkan data-data tersebut di atas dapatlah diperoleh gambaran bahwa kompleks Candi Penataran sudah ada sejak 1119 Ç atau tahun $1197 \mathrm{M}$ dan mengalami perkembangan terus hingga tahun 1337 C atau $1415 \mathrm{M}$. (Sulistyanto, 2000: 13).

Relief cerita yang mengelilingi candi tentu awalnya hanya diketahui oleh para orang tua, kemudian diceritakan kepada orang lain/ anak-anaknya, karena mengandung nilai-nilai filosofi keagamaan. Sebagai contoh cerita Bubuksah dan Gagang Aking yang dipahatkan di relief Candi Pendopo Penataran (Blitar), Jawa Timur. Ke-dua tokoh digambarkan sebagai seorang penganut/ pendeta Siwa (Gagang Aking) dan Buddha (Bubuksah). Cerita yang digambarkan tersebut berlatar filosofi keagamaan, antara dua agama aliran Siwa dan Buddha. Secara substansial, inti ajaran dan tujuannya sama-sama benar. Hanya berbeda dari sudut pandang cara mengaplikasikan ajaran tersebut, sesuai karakter kedua tokoh. Berikut ini, gambar relief dari Candi Penataran, gambar yang ditampilkan adegan pada saat harimau mendatangi kedua orang kakak-beradik tersebut. Relief di Penataran terletak di sisi timur bagian belakang Candi Pendopo. Bahan yang digunakan untuk candi dari jenis batu andesit yang di pasang dengan menggunakan teknik kaitan/ kancingan pada bagian sisi dalam, sehingga saling mengikat dan kokoh.

\section{Relief \\ Bubuksah-Gagang \\ Aking:}

- Harimau mendatangi seorang pria sedang bersila memakai jubah/ gelungan di kepalanya, berbadan gemuk.

- Sementara itu, di latar

- tampak seorang laki-laki bertubuh kurus dengan rambut digelung/ ikat ke

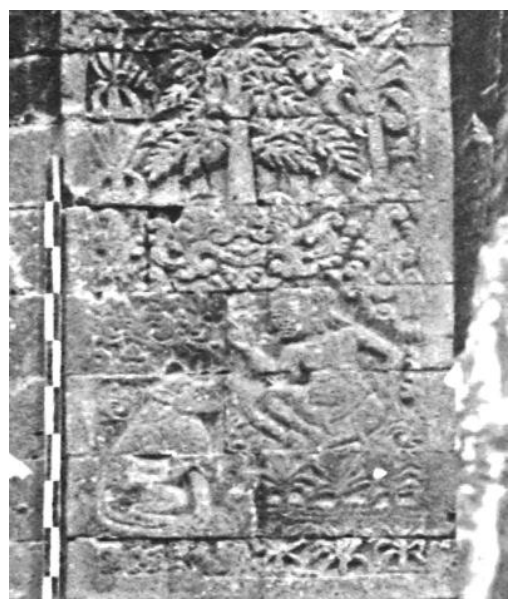

Gambar 2. Candi Surawana:

Gagang Aking menunjukkan arah keberadaan Bubuksah kepada Harimau

(Sumber: Sumber: Balar D.I. Yogyakarta).

belakang sedang berjalan di tengah hutan.

\section{B. Relief Candi Surawana}

Candi Surawana terletak di Desa Canggu, Kecamatan Pare, Kediri, Jawa Timur. Mengenai masa pendirian candi, dihubungkan dengan peristiwa Çradha ${ }^{4}$. Berdasarkan

4 Çradha: Perkataan çradha (sraddha) dalam bahasa Sanskerta berarti selamatan bagi orang yang telah meninggal (Williams, 1963: 197). Upacara ini juga di kenal di Bali sebagai pengorbanan atau selamatan bagi orang yang telah meninggal. Pada masa Jawa Kuna-pun peringatan ini dikaitkan dengan pendirian bangunan pemujaan/ candi. 
Kitab Pararaton, Raja Wengker meninggal pada tahun 1388 C dengan demikian Candi Surawana didirikan sekitar tahun 1400 Ç atau 1478 M. Sementara itu, di dalam Nagarakretagama 62: 2 disebutkan, bahwa pada tahun 1361 M. Raja Hayam Wuruk telah berkunjung dan bermalam di "curabhana sudharma". Jika benar yang dimaksudkan dengan curabhana sudharma di dalam Nagarakretagama itu adalah Candi Surawana sekarang, maka dapat diperoleh gambaran bahwa candi ini harus sudah ada pada tahun 1361 M (Sulistyanto, 2000: 17).

Dua buah relief yang berbeda cerita akan diuraikan, pertama relief Bubuksah-Gagang Aking, dan kedua relief Burung Belibis dengan ikan. Relief Bubuksah-Gagang Aking terletak di sudut Timur Laut. Sedangkan relief Burung Belibis terletak di sisi timur atau bagian belakang candi.

Relief

Aking:

\section{Bubuksah-Gagang}

- Seorang laki-laki dengan rambut digelung/ diikat bagian belakang, sedang berbicara dengan seekor harimau.

- Laki-laki tersebut tangannya menunjuk ke suatu arah.

\section{Relief Burung Belibis}

Relief candi lain yang menarik, adalah Candi Surawana, perlu teliti untuk melihatnya,

Upacara çradha, pernah dilakukan di Majapahit setelah 12 tahun meninggalnya Gayatri, isteri Krtarajasa Jayawardhana (Raden Wijaya) dalam prasasti tembaga Sukamrta yang bertarikh 1296 M (Istari, 1982: 33). karena beberapa bagian sudah mulai aus, sehingga gambar menjadi kurang jelas. Gambar relief ini di dalam etnografi masyarakat Jawa dan Bali sangat dikenal sampai sekitar tahun 1970-an, kemudian saat ini jarang yang mendongengkan lagi.

\section{Adegan:}

- Burung belibis ${ }^{5}$ berjambul/ mahkota, berdiri di sebuah telaga yang penuh dengan ikan.

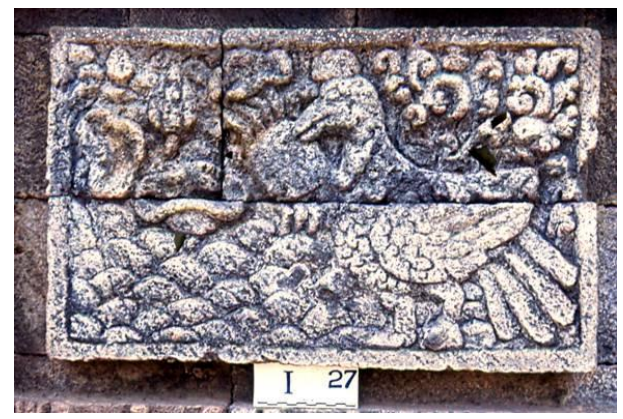

Gambar 3. Candi Surawana:

Burung belibis dengan ketam di leher dan Ikan-ikan di sebuah telaga.

(Sumber: Balar D.I. Yogyakarta ).

- Seekor kepiting menggantung dileher burung tersebut.

\section{Jalannya cerita: \\ Belibis menyamar sebagai} pendeta berdiri di tepi telaga, berpura-pura sedih. Sekelompok ikan mengerumuninya dan bertanya, mengapa ia bersedih? Belibis menjawab bahwa ia bersedih, karena telaga ini akan kering dan seluruh penghuninya akan mati. Diantara ikan-ikan ada seekor kepiting (yuyu) menaruh curiga terhadap belibis, karena ia adalah pemangsa ikan telaga tersebut. Himbauan Sang

\footnotetext{
${ }^{5}$ Belibis (latin= dendrocyna arcuata), nama latin. Sejenis bebek tetapi bisa terbang, salah satu makanan utama tumbuhan dan ikan kecil, biasa hidup di rawa-rawa. Dalam relief digambarkan memiliki jambul/ mahkota, karena ia berpura-pura menjadi pendeta.
} 
Kepiting tidak dipercaya oleh para ikan.

Satu persatu ikan dipindahkan ke suatu tempat yang agak jauh, sebuah batu besar untuk dimangsa, kini tiba giliran si kepiting yang akhirnya mau dipindah dengan berpegangan/ menyapit leher belibis. Betapa terperanjatnya Sang Kepiting melihat tumpukan duri di atas batu padas. Pasti sahabat-sahabatku dimakan Belibis, lalu ia mengancam minta diantar kembali ke tempat semula. Sampai di telaga, lalu dicapit sampai putuslah leher belibis tersebut hingga menemui ajalnya.

\begin{tabular}{lr} 
Dongeng & \multicolumn{2}{r}{ tersebut } \\
memberikan pelajaran yang & yerharga, bagaimana \\
bita \\
mengendalikan diri & dan
\end{tabular}
mewaspadai pada karakter orang yang berperingai jahat/ buruk, tiba-tiba menjadi santun. Biasanya mempunyai niat yang kurang baik, dengan berpura-pura menolong tetapi justeru menjerumuskan. Dalam menjalani hidup sehari-hari, harus waspada terhadap tipu daya seseorang. Dengan berperilaku sabar, dan berpikir sebelum bertindak untuk mengambil suatu keputusan, tentu akan menyelamatkan kita.

\section{Isi Cerita relief Bubuksah-Gagang Aking ${ }^{6}$ Candi Penataran dan Surawana.}

6 Cerita ini ada berbagai versi yang substansinya kadang cenderung membenarkan salah satu agama tertentu. Hemat kami hal itu perlu diluruskan. Pada masa Jawa Kuna Siwa-Buddhis adalah satu, sama-sama saling menghormati dan berjalan beriringan. Bahkan keduanya memunculkan sinkritisme utamanya dalam cerita, mitosmitos dan dalam bentuk relief candi, yang kemudian muncul pada waktu itu.
Dahulu kala hiduplah dua bersaudara kakak-adik yang hidup rukun, setelah berguru pada seorang resi, keduanya berniat ke hutan/ gunung untuk mencari kesempurnaan hidup sebagai pertapa. Sang kakak bernama Bubuksah berbadan besar dan gemuk, sedangkan adiknya berpostur kurus kering dan kecil bernama Gagang Aking. Setelah sampai di hutan, masing-masing mencari gua untuk bertapa. Bubuksah berada di sisi timur sungai menghadap ke barat, sedangkan Gagang Aking berada di gua sisi barat sungai menghadap ke timur. Keduanya menjalani kehidupan berdasarkan pengetahuan/ pencerahan yang mereka peroleh dari seorang resi. Sesuai dengan pemahaman masing-masing, Bubuksah dalam kehidupan seharihari selalu memakan dan minum apa saja yang dapat ia makan, termasuk segala binatang, tumbuhan yang ada di sekitarnya dan badanya menjadi semakin gemuk. Sementara itu, Gagang Aking lebih banyak melakukan puasa dengan tidak memakan apapun, sehingga badannya menjadi semakin kuruskering. Pertapaan kedua saudara ini, menimbulkan keperihatinan Dewa Indra. la melapor kepada Dewa Siwa tentang niat kedua pertapa tersebut. Akhirnya diutuslah Sang Kalawijaya

Contohnya adalah cerita Bubuksah-Gagang Aking merupakan kearifan lokal nenek moyang, dengan tujuan memberikan contohcontoh kebenaran dan kekekalan ajaran Siwa-Buddhis dan Kepercayaan asli Indonesia. Adapun mengenai pakaian yang dikenakan ke-dua tokoh sebagai tanda untuk membedakan antara keduanya yang berbeda pandangan/ tentang konsepsi religius. Oleh karena itu, dua alian tersebut 'berbaur' menjadi satu berkat kearifan lokal bangsa kita yang menyatukan dua konsep/ pandangan tersebut menjadi satu keyakinan. 
turun ke dunia dengan menjelma menjadi harimau putih.

Pertama kali harimau putih mendekati Gagang Aking, sambil mengaum keras, ia berkata ..."Hai manusia, aku sakit dan hanya akan sembuh jika makan daging manusia..." Dengan rasa takut dan badan gemetar ia menjawab, ..."percuma kamu makan dagingku yang kurus dan sedikit, tak akan membuatmu kenyang. Datanglah ke gua di seberang sungai itu, ada saudaraku gemuk dan sehat..." Sang harimau putih, segera mendatangi Bubuksah sambil menyampaikan permintaan yang sama. Sungguh tidak disangka, Bubuksah mempersilahkan menyantap dirinya kalau memang bisa menyembuhkan penyakit dan kelaparannya. ..."Aku sudah lama hidup di dunia dan memakan segala yang ada, kalau memang aku harus kamu makan, sudah takdirku mati untuk menolongmu..." Harimau putih mengakui bahwa dirinya adalah Kalawijaya, yang di utus oleh Dewa Siwa. Kemudian kedua bersaudara itu diajak ke Swargaloka, Bubuksah duduk di punggung dan Gagang Aking bergelantungan pada ekornya. Keduanya memperoleh ganjaran, karena telah melakukan pertapaan yang berat, lalu diantar oleh Kalawijaya naik ke surga.

Makna dari cerita tersebut, Bubuksah melakukan kegiatan ritual dan kehidupan sehari-harinya dengan tanpa pamrih dan menyerahkan seluruh hidup-matinya pada Kuasa Alam, suatu penyerahan diri (jiwa-raga) secara total. Totalitas itulah yang menyelamatkan jiwa, sehingga memperoleh kebahagiaan abadi (simbolis duduk di punggung harimau). Sementara itu, Gagang Aking dalam memaknai ajaran tersebut, masih 'diikat' oleh hal-hal yang bersifat duniawi. Artinya, dalam menjalani kehidupan ini, masih memperhitungkan pamrih/ pahala (untung-rugi) yang diinginkan. Tidak melakukan ajaran kehidupan secara total/ pasrah kepada 'Kuasa Alam', sehingga hanya memperoleh surga yang kedua (simbolis dari ekor harimau).

\section{Candi Mendut}

Cerita yang mengandung nilainilai edukatif, biasanya diperankan oleh binatang (fabel), seperti di Candi Mendut di Magelang, Jawa Tengah, mengisahkan tentang persahabatan kura-kura dengan burung bangau. Pesan yang disampaikan dalam relief tersebut sangat menarik untuk anak-anak sebagai bagian dari edukatif kultural.

Candi Mendut terletak di Kecamatan Mungkid, Kabupaten Magelang, Jawa Tengah, diperkirakan candi ini dibangun oleh Wangsa Syailendra pada tahun 824 $\mathrm{M}$, berdasarkan pada isi Prasasti Karangtengah (824 M), yang menyebutkan bahwa Raja Indra telah membuat bangunan suci bernama Wenuwana (hutan bambu). Candi menggunakan bahan batu andesit dan bersifat keagamaan Buddha. Candi ini sampai sekarang masih digunakan sebagai tempat ritual umat Budha dan pusat perayaan Waisak.

\section{Relief Candi Mendut \\ Adegan :}

- Dua ekor burung bangau sedang terbang menggenggang ranting.

- Ditengahnya seekor kura-kura bergelantungan menggigit ranting itu.

- Sekawanan gembala meneriaki sambil memanah kura-kura. 
- Kemudian, kawanan tersebut menyantap kura-kura.

Jalannya cerita:

Persahabatan

sepasang bangau dan kura-kura

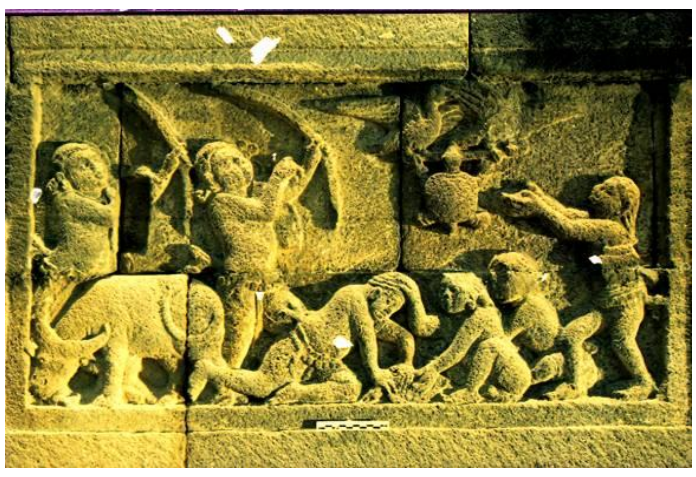

Gambar 3. Candi Mendut:

Bangau menolong kura-kura untuk dipindahkan. Melewati kelompok pengembala kerbau.

(Sumber: Balar D.I. Yogyakarta).

sudah berlangsung lama. Sampai pada suatu ketika, bangau sedih karena telaga tersebut akan kering akibat musim kemarau yang sangat panjang. Hal tersebut ia ceritakan kepada sahabatnya, lalu mereka sepakat untuk memindahkan pada telaga yang bermata air dan tidak akan kekeringan. Sebelum memindahkan, bangau berpesan kepada kura-kura, selama terbang menggigit ranting tersebut tidak boleh membuka mulut atau berkata sepatah kata-pun. Kura-kura menyanggupinya, lalu mereka terbang mengangkasa melewati sungai-sungai dan telaga kecil yang kering airnya.

Sampailah mereka, ketika melewati padang rumput yang luas, tampaklah sekawanan anak-anak sedang mengembalakan sapi/ kerbau sambil bersendau-gurau. Mereka memandang ke angkasa, dilihatnya ada suatu bayangan yang aneh. Ketika semakin dekat, tampak jelas yang dilihatnya, ternyata dua ekor bangau sedang mengangkat kura-kura di tengahnya. Mereka berteriak-teriak nyaring sambil melempar, dan memanahnya, karena daging kura-kura sangat lezat. Menggunakan batu dan anak panah percuma, karena jangkauannya terlampau jauh, mereka mulai mengejek, ..."Hei kawan-kawan, lihatlah ada binatang yang sangat bodoh, menerbangkan kotoran kerbau kering (tlethong garing) ${ }^{7} " .$. Sambil bersorak-sorai dan mengejek, itulah yang membuat kura-kura menjadi naik pitam (emosi), karena dirinya dikatakan 'kotoran kerbau kering'. Saking marah dan dongkolnya, lalu berniat menjawab ..."aku bukan kotoran kerbau, aku raja kura-kura"... Belum sempat kata-kata tersebut diucapkan, Sang kura-kura sudah melayang, karena gigitan pada ranting lepas dan jatuh ke tanah, kemudian dimasak oleh para gembala dan disantap bersamasama.

Cerita di atas ingin menyampaikan, bahwa pesan dari sahabat/ orang tua harus diingat dan dituruti, tidak boleh emosi, bersabar sampai setelah mencapai tujuan. Gangguan dan godaan adalah ujian terberat, karena itu harus tetap fokus pada prinsip/ pendirian, agar tercapai tujuan yang sesungguhnya (kehidupan).

Empat buah panil relief cerita dari tiga buah candi, memberikan gambaran bahwa relief berperan penting dan dimanfaatkan oleh penguasa, sebagai salah satu sumber informasi. Berkaitan dengan konsep-konsep religius dalam bentuk simbol-simbol cerita dan dongeng untuk disebar-luaskan kepada masyarakat. Dalam proses sosialisasinya, terjadi komunikasi antara anggota masyarakat satu

\footnotetext{
${ }^{7}$ Bahasa Jawa, Tlethong $=$ kotoran sapi, kerbau, dan kuda, garing $=$ kering.
} 
dengan lainnya, namun tetap mengacu pada apa yang dilihat dan diketahui dalam gambar relief tersebut. Unsur cerita yang ditampilkan di depan, terdapat dua versi yang agak berbeda, tetapi mengacu pada konsep-konsep keagamaan yang sama: Pertama, cerita Bubuksah-Gagang Aking kemungkinan ditujukan bagi kalangan orang dewasa, karena mengandung nilai-nilai filosofis keagamaan yang berkembang pada waktu itu; Sedangkan yang Kedua, dongeng tentang Kura-Kura Bangau dan Belibis Kepiting, ditujukan bagi anak-anak. Dalam versi fabel, kehidupan manusia baik watak dan tingkah laku sehari-harinya diperankan oleh binatang-binatang yang lucu, cerdik dan pandai, sehingga mudah diingat oleh anakanak. Proses komunikasi tersebut merupakan transfer pengetahuan dari satu orang keorang yang lain dan jumahnya dapat tidak terbatas. Penyampaian pengetahuan tersebut merupakan materi pendidikan moral berdasarkan pada konsep keagamaan. Sehingga lambat-laun masyarakat akan mengikuti, menirukan pesan-pesan moraldidaktif tersebut di dalam kehidupan sehari-hari.

\section{RELIEF CANDI PENATARAN, SURAWANA DAN MENDUT SEBAGAI MEDIA INFORMASI}

\footnotetext{
Pendirian bangunan suci, dengan bentuk bangunan yang megah, tentunya diprakasai dan diperintahkan oleh seorang raja untuk melakukan pemujaan kepada para dewa. Sebagai bangunan suci, merupakan tempat berkumpulnya orang-orang dari seluruh penjuru untuk melakukan ritual. Sementara itu, candi juga dilengkapi dengan hiasan-hiasan relief yang berfungsi
}

untuk memperindah candi, selain memiliki makna simbolis, berperan pula sebagai media informasi. Pesan yang disampaikan berhubungan dengan nilai-nilai religius dan sosial. Sebuah candi belum tentu didirikan dipusat pemerintahan, tetapi bisa di desa-desa (wanua) yang dianggap berperan dan berjasa pada raja. Desa berperan penting dalam mendukung struktur birokrasi pemerintahan raja. Menurut Soesanti (1986), satuan wilayah terkecil adalah wanua, dan data prasasti mencatat bahwa setiap wanua dipimpin oleh beberapa orang rãma yaitu dewan pimpinan wanua. Kemudian beberapa wanua (desa) bersekutu membentuk suatu kelompok yang disebut watak dan bergantung pada pimpinan seorang pejabat tinggi yang disebut rakai (Soesanti, 1986: 305). Hal ini berkaitan dengan pendirian Candi Penataran dan Surawana yang belum tentu didirikan di pusat pemerintahan, tetapi kemungkinan justeru di daerah wanual watak. Sampai saat ini, pusat-pusat pemerintahan (keraton) masih belum pernah ditemukan artefak maupun indikator-indikator yang menunjukkan secara jelas.

Pendirian Candi Penataran Tahun 1375 M dan Candi Surawana tahun $1361 \mathrm{M}$, membuktikan bahwa cerita/ mitos tersebut telah berkembang pesat atau dianggap penting untuk disosialisasikan kepada rakyatnya. Informasi tersebut, diharapkan dapat menjadi inspirasi, pandangan dan pedoman hidup. Sementara itu, penggambaran relief yang berkaitan dengan dongeng kemungkinan sasaran ditujukan untuk anak-anak. Digambarkan Kura-Kura dengan Bangau (Candi Mendut), dan Belibis dengan Kepiting (Candi Surawana). Kedua candi letaknya berjauhan, di 
Jawa Tengah (abad ke-8 M) dengan Candi Surowono di Jawa Timur (abad ke-14 M). Kronologi waktu dan jarak yang relatif jauh tersebut, membuktikan pentingnya dongeng/ cerita tersebut untuk diinformasikan dan dipahami oleh masyarakat Jawa Kuna.

Berkaitan dengan pendapat Soesanti di depan, maka Casparis memberikan penjelasan berdasarkan sumber prasasti dapat diketahui, bahwa setiap wanua memiliki sejumlah pejabat wanua yang mengurusi kehidupan seharihari penduduk desa. Kemudian watak sebagai wilayah otonom juga mempunyai organisasi pemerintahan sendiri; sedangkan pusat pemerintahan terdiri atas raja sebagai pucuk pemerintahan dibantu oleh para pejabat tinggi kerajaan. Jadi, raja adalah tempat tertinggi yang membawahi para pejabat tinggi kerajaan, pejabat-pejabat watak dan pejabat-pejabat wanua (Casparis, 1983: 7). Adanya struktur pemerintahan yang jelas dari pusat/kerajaan sampai ke paling bawah (wanua), hirarki tersebut tentunya mempermudah jalur-jalur komunikasi dan informasi sampai ke masyarakat.

Pendirian bangunan suci, baik di pusat kerajaan (core) maupun di luar kerajaan (periphery) tentu berkaitan dengan masalah strategi pemerintahan dan politik. Pendirian candi bisa dilakukan dengan kemungkinan sebagai peringatan upacara 12 tahun meninggal (Cradhha), atau berkaitan dengan politik yaitu penghargaan terhadap kepala daerah yang telah berjasa terhadap raja. Dalam konteks ini, penguasa ingin membangun komunikasi agar tetap terjaga dengan baik antara core dan periphery. Melalui cerita fabel dan Bubuksah Gagang Aking yang telah dikenal sejak abad ke-8 sampai dengan ke-14 Masehi. Cerita tersebut dapat menambah pengetahuan masyarakat akan soal keagamaan dan tuntunan moraldidaktif. Oleh karena itu, pendirian bangunan suci di luar pusat kerajaan salah satu fungsinya untuk penyebaran, media komunikasi/ informasi agar 'mengakar' pada rakyatnya. Komunikasi mempunyai arti penting dalam penyebaran informasi kepada masyarakat, dengan adanya komunikasi, komunikator sebagai pencetus ideide, dapat menanamkan idenya secara perlahan-lahan untuk mencapai persesuaian dengan kehidupan dan tujuan masyarakat (Prabukusumo, 2009: 26).

Dalam setiap bentuk pemerintahan, monarkhi, demokrasi maupun republik tentu diperlukan suatu alat komunikasi untuk menjembatani antara pemerintah pusat, daerah dengan masyarakatnya. Hal tersebut juga terjadi pada masa Jawa Kuna, teknologi media yang dikenal waktu itu, barulah dalam bentuk relief candi, prasasti, lontar untuk menyampaikan pesan. Prasasti dan lontar merupakan barang bergerak yang mudah rusak atau hilang, sedangkan pesan yang disampaikan dalam bentuk relief di candi-candi tetap abadi kalau tidak dirusak oleh manusia/ alam. Bedanya dalam relief digambarkan dalam bentuk cerita atau simbolis flora-fauna, sedangkan prasasti dan naskah lontar berupa tulisan. Relief cerita pada dinding candi, salah satu sumber asli tentang konsep-konsep keagamaan/ moral-etika, sebagai pusat informasi penting. Kemudian informasi yang digambarkan pada relief berupa cerita tersebut, disebarluaskan kepada masyarakat dalam suatu proses pendidikan dan 
pengajaran secara oral untuk menanamkan nilai-nilai luhur dan budi pekerti. Sebenarnya, makna informasi relief tidak terbatas pada konteks religius saja, tetapi dapat dikaitkan dengan nilai-nilai hidup bermasyarakat secara luas, seperti tentang saling menghargai, toleransi dan kebersamaan.

\section{KESIMPULAN}

Para penguasa Jawa Kuna, mendirikan bangunan suci berupa candi-candi tentu bertujuan untuk menunjukkan kekuasaannya dan memberikan kesejahteraan ,spiritual bagi masyarakatnya. Candi-candi yang dibangun pada abad ke-8 sampai dengan ke-14 Masehi, meninggalkan bentuk budaya yang bernilai tinggi, baik budaya materi maupun berupa nilai-nilai. Candi dengan hiasan reliefnya merupakan satu kesatuan yang tidak dapat dipisahkan, sebagai pusat religi, pengetahuan dan edukatif yang diwakili oleh cerita-cerita yang dimuat di dalam panil-panil relief. Di antara cerita tersebut yang cukup dikenal hingga sekarang, khusunya: di Candi Mendut cerita Angsa dengan Kura-Kura; Candi Penataran cerita Bubuksah-Gagang Aking; Candi Surawana cerita Bubuksah-Gagang Aking dan Belibis dengan Kepiting.

Candi sebagai salah satu pusat religi dan simbol-simbol kekuasaan raja, merupakan salah satu tempat atau media untuk menyebar-luaskan 'pengaruh' yang diinginkan oleh penguasa. Para nenek moyang dengan kearifan lokalnya memadukan pengaruh 'asing' secara harmonis dengan alam lingkungannya yang tentu saja memilih hal-hal yang tidak bertentangan dengan budaya/ adat istiadat setempat. Perpaduan tersebut memunculkan bentukbentuk mitos, cerita/ dongeng dalam relief cerita yang sarat dengan muatan edukatif dan budi pekerti. Hal tersebut merupakan sebuah komponen yang sangat penting dalam rangka membentuk kepribadian bangsa, dalam rangka pembangunan mental dan ideologis.

Relief candi merupakan sebuah media yang digunakan oleh penguasa, sebagai media komunikasi dan informasi dalam membentuk moral yang sangat efektif. Sampai saat ini masih terdengar dongeng maupun cerita tersebut dalam kehidupan beberapa kelompok masyarakat yang tersebar di Jawa. Oleh sebab itu, nilai-nilai yang terkandung dalam cerita tersebut tetap relevan dan dapat menjadi model, serta memberikan kontribusi dalam materi pendidikan anak/ sekolah, khususnya pendidikan budi-pekerti. Sebagai harapan ke depan, budi-pekerti menjadi pilar penting dalam membentuk karakter Bangsa Indonesia, supaya tidak kehilangan jatidirinya sebagai bangsa yang besar dan santun.

\section{SARAN}

Internal:

- Selama ini, kajian lembagalembaga arkeologi tentang percandian belum terintegrasi dengan baik, masyarakat masih banyak yang belum mengetahui secara jelas makna dan fungsi pada masa lalu, dan manfaatnya masa kini. Selama ini, pandangan masyarakat masih pada tahap budaya materi/ material culture yang dapat menimbulkan perbedaan persepsi. Oleh sebab itu, perlu dipikirkan penjelasanpenjelasan dari sudut pandang budaya intangible yaitu berupa 
pandangan mengenai nilai-nilai dan aspek-aspek yang hidup dalam konteks masyarakat pendukung budaya/ candi tersebut. Sehingga antara keterangan (budaya materi) dan penjelasan (budaya non-materi) berupa nilai-nilai tersebut dapat saling melengkapi, dan dimengerti secara utuh oleh masyarakat luas.

\section{Eksternal:}

- Bagi stakeholder, lembaga/ dinas pariwisata, dan pemandu wisata/ guide untuk lebih mendalami dan mengerti candi yang tidak hanya dilihat unsur fisik arsitektural, melainkan 'roh' dan hubungan emosional antara masyarakat dengan candi pada masa lalu.

- Mari kita jaga cagar budaya yang merupakan jatidiri bangsa dengan ikut merawat dan melestarikan, karena candi adalah salah satu 'identitas dan wajah budaya kita'.

\section{UCAPAN TERIMA KASIH}

Terimakasih yang sebesarbesarnya kepada mitra bestari yang dalam kesibukannya berkenan meluangkan waktu, memberikan arahan, bimbingan dan sumbangsaran dalam penyelesaian tulisan. Diharapkan tulisan sederhana ini, dapat bermanfaat bagi para pembaca yang ingin mengetahui, tentang peran relief candi sebagai media komunikasi/ informasi masa Jawa Kuna. 


\section{DAFTAR PUSTAKA}

Atmosudiro, Sumijati (editor) dkk. 2008. Jawa Tengah sebuah Potret Warisan Budaya - Balai Pelestarian Peninggalan Purbakala Jawa Tengah dan Jurusan Arkeologi Fakultas IImu Budaya, Yogyakarta - Universitas Gadjah Mada.

Casparis, J.G. de. "The Evolution of the Socio-economic Status of the East Javanese Village and its Inhabitante", Papers of the fourth IndonesianDutch History Conference. Yogyakarta 24-29 July 1983. Volume One: Agrarian History. Yogyakarta: Gadjah Mada University Press.

Istari, Rita. 2011. "Ragam Hias Candi-Candi di DIY, Jawa Tengah, dan Jawa Timur", Laporan Penelitian Arkeologi (LPA), Yogyakarta: Balai Arkeologi.

1982. "Upacara Sraddha dan Kaitannya dengan Upacara Kematian Lainnya pada Masyarakat Indonesia", Skripsi Sarjana Muda. Yogyakarta: Fakultas Satra dan Kebudayaan Universitas Gadjah Mada.

Koentajaraningrat, 1980. Pengantar IImu Antropologi - Aksara Baru - Jakarta.

Liliweri, Alo, M.S. 2007. Dasar-Dasar Komunikasi Antarbudaya (cetakan ke-3) Yogyakarta - Pustaka Pelajar.

Prabukusuma, Pantiyo Nugroho, 2009. Komunikasi dan Transformasi Sosial Yogyakarta - B2P3KS Press.

Sedyawati, Edi, 2009. Saiwa dan Buddha di Masa Jawa Kuna - Departemen Agama RI, Ditjen Bimas Hindu Tahun Anggaran 2009 - Denpasar: Widya Darma.

Soesanti, Ninie, 1986. "Mekanisme Birokrasi di Jaman Raja Balitung (898-910 M)", Pertemuan IImiah Arkeologi (PIA) IV, Cipanas 1986. Jawa Barat. hlm. 305

Subadio, Haryati. 1986. Kepribadian Bangsa - Penyunting Ayatrohaedi, Kepribadian Budaya Bangsa (Local Genius) - Pustaka Jaya - Fak. Ekonomi, Bandung. Jakarta: diterbitkan atas kerjasama dengan Ikatan Ahli Arkeologi dengan PT Dunia Pustaka Jaya.

Sulistyanto, Bambang. 2000. "Mitos Bubuksah Kajian Struktural dan Maknanya", Berita Penelitian Arkeologi (BPA), Yogyakarta: Balai Arkeologi.

Williams, M. Monier, 1963. "A Sanskrit English Dictionary", Oxford: University Press. 
.Klokke, J Marijke, 1993. "Tantri Reliefs on Javanese Candi” KITLV Press, Leiden.

Departemen Pendidikan Nasional 2012: Kamus Besar Bahasa Indonesia Edisi Keempat - Gramedia Pustaka Utama 